\title{
A world in making
}

\author{
Suzie Attiwill
}

The call for papers for this issue invited contributions that attend to and address craft and design practices in relation to the urban environment when, for the first time in history, more than half the world's population lives in cities. Titled A World in Making. Cities Craft Design, the call played with different inflections of 'a world in making': as an immersion in a world of making, of craft and design, of practitioners and practice, of matter and techniques, and an approach to understanding 'world' as something made and always in making - 'a worlding' (Massumi 2002: 128; Murphie 2008: 2).

The in-ness of 'a world in making' flags the interests I bring to the topic of craft and design in this issue \#5 of the craft + design enquiry journal. My practice and research is situated within the discipline of interior design. Through practices of interiorization, the question 'interior' is posed as a contemporary problematic where interior is not defined in advance as being inside something, but is produced through designing. I am interested in interior design as a practice of interior-making, which attends to questions of interior and interiority in relation to habitation (Attiwill 2013).

Urban Interior, a research group with which I am involved, addresses these issues through a focus on the relation between people and the urban condition, and the material, sensory, physiological, cultural and experiential dimensions that create and affect social relations. Questions posed by the group include: What might be the contribution of design disciplines to new modes of urban inhabitation? How can temporary, interrelated design actions in urban conditions mediate the qualities needed to sustain and enrich the increasing inhabitation of urban areas? Within this research group, I am interested in the conjunction between urban and interior in relation to the built fabric as well as people's relation to and inhabitation of the urban environment - physical, psychological and social. ${ }^{1}$ I invented a persona for this practice - an 'urban interiorist' - who attends to the conjunction of urban + interior through a range of techniques and experiments. $^{2}$

My interior design practice is also shaped and influenced by craft. From 1996 to 1999 I was the artistic director of Craft Victoria - a craft organisation in Melbourne, Australia - where I learnt the potential of craft. During this time I was the editor of Craft - Craft Victoria's magazine - which became a critical

1 This refers to Félix Guattari's concept of the three ecologies: environmental (physical), mental (human subject) and social (relations) ecologies (Guattari, 2008).

2 Publications include: (Attiwill 2011; 2008). 
vehicle for the publication, advocacy and dissemination of the value of craft. In a curious coincidence, Urban Interior held one of its events, Urban Interior Occupation, in the Craft Victoria galleries during September $2008 .^{3}$

Plied with an interior design practice, craft works with spatial and temporal concerns to produce a space crafting that is attentive to signs of matter, a privileging of the haptic (a tendency that invites close attention) as distinct from the optic (a tendency towards detachment), a working and reworking that differs from design techniques of abstraction.

The effects and affects of craft in relation to design were invited to be explored in the call for papers for this issue:

Nuances of craft - a practice which values making and materiality - will be foregrounded in the selection of papers for publication. This emphasis on craft does not exclude design so much as bring attention to practices of design which engage ideas of making and materiality, where there is a sense of a hand(s) in making, a valuing of haptic encounters and an attention to the relation between people and surroundings. From small to large-scale projects, from individuals to communities, an intimate approach to the question of how people inhabit and transform the urban environment is invoked.

\section{In/habitation}

Both craft and interior design are practices situated between people and things and/or environments, making relations of closeness and immediacy as lived, live and living relations.

As such, both practices have much to contribute to modes of habitation and the urban environment. Considering this issue now, in relation to the contemporary city, the transformations of cities over the past century becomes apparent in a comparison between Australia's capital city, Canberra, in the year 2013 and and the year of its founding, 1913.

Again, from the call for papers:

On 12 March 1913, a naming ceremony took place in an empty paddock on a hill. This rural environment was to become a city, the capital city of Australia, the city of Canberra. The aspirations and the projections of the Griffins' winning design for Canberra are an example of a world-in-making involving the practices of design and craft. This issue of craft + design enquiry will be published in $2013-100$ years after this event and when, for the first time in history, more than half the world's population lives in cities ...

3 Visit Urban Interior website: http://www.urbaninterior.net/index.php?action=pdetails\&option=35 
The twenty-first century has been called 'the century of the city' (Tibaijuka 2010) due to significant shifts in urban population and the impact this is having, and will have, on cities and urban density, as exemplified in the emergence of meta-cities with populations of 20 million people. Concepts of place and modes of living are brought into question. Precedents from previous centuries have become inadequate as references to work with and address contemporary forces of globalism and mass migration. The world is not coded as it was before; there is a diminished feeling of being in place. 'Globalisation has evicted us from the world we thought we knew'. (Buchanan \& Lambert 2005: 7) Relations between environments and people have changed significantly; in particular with regard to spatial relations, such as public/private, inside/outside, near/far. A sense of remoteness and vastness couples with technological immediacy and produces a loss of human scale and proportion. Movement and mobility have produced a mobile subject where 'we are doing the lurching, not the earth'. (Buchanan 2005: 19)

In the midst of these forces, the potential of craft and design practice is posed with a focus on making and attending to the contemporary urban environment of cities. In the call for papers, I used a quote from philosopher Elizabeth Grosz's essay 'The thing'. I return to this text to think about objects and craft as it provokes a rethinking not only of objects but also the question of the subject in relation to making.

\section{Grosz writes:}

The thing is the precondition of the living and the human, their means of survival, and the consequence or product of life and its practical needs. The thing is the point of intersection of space and time, the locus of the temporal narrowing and spatial localisation that constitutes specificity or singularity.

The following is an extended quote, completing the abbreviated text that was included in the call for papers:

The thing is what we make of the world rather than simply what we find in the world, the way we are able to manage and regulate it according to our needs and purposes ... The thing is an outlined imposition we make on specific regions in the world so that these regions become comprehensible and facilitate our purposes and projects, even while limiting and localising them. Things are our way of dealing with a world in which we are enmeshed rather than over which we have dominion. ... It is our way of dealing with the plethora of sensations, vibrations, movements, and intensities that constitute both our world and ourselves ...

We make objects in order to live in the world. Or, in another, Nietzschean sense, we must live in the world artistically, not as homo sapiens but as homo faber. (Grosz 2009: 125, 126, 128)

Here, making involves relations with movement - a slowing down, to coalesce, to stabilise and enable inhabitation through making specific, producing a 
'temporal narrowing' and 'spatial localisation'. This is not only a process, say, of making objects and physical space within which social relations can happen, such as eating, sleeping or entertaining; it is also a process that makes subjects. 'To meld the world into things ... to fit the needs of the living ... making oneself as one makes things'. (Grosz 2009: 130)

The potential with this way of thinking and also as a positioning of, and for, craft and design practice is extended in this issue to jewellers, weavers, architects, interior designers, graphic designers, product designers, service designers, design historians, landscape architects, urban designers, ceramicists, potters, woodworkers, furniture designers, textile printers, knitters and readers. In this issue the potential of craft as a vital practice in the twenty-first century is posed through an attention to the crafting/making of relations, to reconfiguring matter in the making of objects, subjects and spaces. Attending to the human subject in a haptic world, and the kinds of social relations that emerge from this making and the physical environment - the world in making - enables an inhabitation of cities as a counterpoint to the vastness and remoteness of globalism.

Questions posed in the call for papers were:

What are the potentials in 'this century of the city' for craft and design practices?

What is the contribution of craft and design to cities and live-ability?

What might a craft sensibility bring to urban inhabitation?

What of an expanded idea of craft practice as a way of working and thinking which addresses spatial and temporal urban conditions?

What of the emergence of new forms of practices to engage in the condition of the urban environment and the social, political and cultural forces of the twenty-first century?

\section{Worlds in making}

Each paper invites the reader in, into a worlding produced through different techniques and matter. The papers are produced through practice, through doing as thinking and thinking as doing (Grosz 2001: 59); where research through practice immersed in issues, momentums, interests and forces produces a paper that gathers, brings in close and arranges in a way which enables habitation of a singular world in making.

This issue, too, is a worlding. As a guest editor, I was curious to see what papers might be submitted, what could be collected and arranged. The arrangement of papers alphabetically according to surnames was to avoid a thematic clustering and enable readers and myself to move through the papers and journal in a way that was not predetermined by themes and classification. I was keen for a multiplicity of encounters and different connections to be made with each 
reading and re-reading. Some surprising connections are drawn here in the following text as a way of inviting you into each of the papers, to enable a mobility between them: to begin in the middle, from the back, or here with Jacqui Chan's 'Jewellery, the urban milieu and emergence'.

Chan's paper invites the reader into a series of projects connecting jewellery and cities, specifically the cities of Melbourne, Ramallah and Christchurch. Her making process engages with the material flow of these cities to slow down and reconfigure matter into brooches. In different ways, people are then invited to wear a brooch and move through the city - the urban milieu - making relations. This process transforms people's sense of where they are and invites them to notice differently; qualities surface as affects and intensities create feelings of specificity and connection. Her practice also transformed as she "came to realise that colourising someone's experience, fostering a state of wonderment or provoking interactions with the city was a radical thing for jewellery to do'.

'The generative loom: tapestry in the community' presents a practice of weaving situated within a public space. Woven strips of photographed textile objects from other places are reworked to produce a map of the City of Charles Stuart. People passing slow down to watch Kirsty Darlaston weave and in the process, make connections with their own experiences. Darlston writes about 'a dance of subjectivity' that takes place between the maker and those watching her weave. Distant times and spaces - Iran, Afghanistan and Australia - are brought close together in this world in making and, in a haptic way, they are made present to produce a new space and time. A world in making; 'a tapestry in the community'.

Emergence, a quality in the above two papers, is a focus of Michael Davis's enquiry through his practice as an architect. 'Pursuing a sense of the emergent through craft practices in architectural design' takes the reader into a world in making - Davis's world. It is detailed, rich, thoughtful, precise, evocative, crafty, sensitive, skilful, humorous; the reader moves with Davis through a series of projects to think through how the craft aspect of architectural design practice the representational practices of drawing and model-making - might become present in architectural outcomes. How through the making of representations, 'the attentive practitioner' can distinguish this crafting experientially; to 'develop a feeling for the implications of the artefact being represented at smaller and larger scales - from detail to context, from the front door step to the city'.

The question of representation carries through into 'Crafting the imaginary: The deteriorating idea and sentimental plan of the ideal city'. Erin Hinton and Craig Bremner bring urban design and planning, the practice of making images and the production of the public imaginary together with craft and a practice of crafting. Here, the abstraction of the city through the plan is seen as one which engages crafting, where the plan becomes matter and is distinguished from the ideal plan as a preconceived idea that is imposed. The crafting process requires a dialogue between practice and thinking; '... craft demands listening to its material.' The process of craft - its 'scale, repetition, and purposefulness 
of the process' - allows for the inclusion of consistent interrogation. Hinton and Bremner propose this practice of crafting as an urban practice where 'the constant repair of the fabric and image of the city' becomes 'the nonstop project of craft'.

Processual and hapticity also permeate the landscape architecture practice of Marieluise Jonas and Heike Rahmann situated in urban voids, terrain vagues, overlooked spaces of cities, specifically in Tokyo and Melbourne. Poised as a dynamic urbanism, the challenge of this practice is to intervene in these incidental and delicate spatial and temporal compositions in a way that does not colonise them and submit them to purposeful designs, but enables encounters with landscape and nature as difference. Many cities within one city become apparent. These transitory, fleeting, contingent and poignant moments continually change and transform - a dynamic urbanism. The scale here is different from that usually equated with urbanism - here there is a focus on the experiential, 1:1 scale between people and their surroundings, an attentiveness to that which usually is unnoticed; fostering and nurturing social relations and subjectivities that value the attentive, curious and caring. A practice of both doubt and reward that involves different ways of valuing from that of predetermined measurable outcomes is produced.

Adjacent to these spaces of terrain vague, Matthew Kiem's paper positions the Griffins' design for the capital city of Canberra as a project which effects a total designing: '(Un)making Canberra: Craft and the designing of settlercolonialism in Australia'. In this paper, we also encounter the idea of the city as plan, however, here, design is coupled with the making/(un)making practice of the historian. Kiem's history questions the celebration of craft and design via the Griffins's design for the capital as 'an evocative communication of an imaginary space', noting that this making is also an unmaking; that a world in making, unmakes other worlds, here the 'Ngambri worldhood'. Kiem's project is a history design - a 'design towards decolonial sustainment'. In drawing attention to the dynamics of making and unmaking, the emphasis shifts from 'what' to 'how' and, with this, ethics.

'Crafting social innovators: Designing collaborative, participative, networked solutions in urban contexts' details a series of design studios which engage future designers as well as citizens with processes of learning through doing in relation to developing communities, moving beyond an understanding of design as functional and towards design as a process of producing collaborations and networks. These projects and practices produce what Marzia Mortati and Beatrice Villari have termed a temporary community of makers: 'temporary' around a particular project; 'community' as a 'collective subject' that is different to the sum of its parts, for example, citizens; 'makers' in that 'the community originates to make something that is designing and developing an idea in particular contexts, sharing languages and tools'.

Productions of temporary communities and networks also thread through Mark Richardson, Susie Elliott and Brad Haylock's paper 'This home is a factory: 
implications of the Maker Movement on urban environments'. They articulate a reconfiguration of the design process as one of distributed making where home becomes factory. The previous separation between industrial and residential - a defining division of cities - is no longer relevant and what we see and experience is a 'conflation of domestic, industrial and retail zones'. There are now "“maker-friendly" cities', new objects and subjects, and the role of designer and maker is recombined in new ways to produce a global network of innovators.

\section{In}

The papers in this issue invite the reader into worlds that are in process of making and unmaking, emerging, mobile and changing; producing subjects, objects and spaces; enabling temporal clusters as temporary communities where each person becomes maker and participant in a creative process.

During the process of making this issue, assumptions about craft became apparent as some people struggled to understand the potential between craft practices and cities. The familiar role of craft within the urban context is as a form of public art, however, as you read through the papers, many other practices which connect craft and cities become apparent and, in turn, transform understandings of craft practice and its contribution. The struggle to bring craft and cities together is perhaps due to a perceived disjunction between the intimate scale of craft and the complexity of cities. Yet, it is this disjunction between craft and cities, between different scales, between intimacy and remoteness, that heightens the poignancy and potency of craft practices in this contemporary globalised world. The papers here contribute to grasping the potential of this practice in their detailed forays into cities and practice to produce worlds in making, where craft and design practices are engaged with as vital urban practices, as practices of cities.

While implicit in the call for papers, an attention to 'how', as distinct from 'what', also becomes apparent and, hence, the effect and affect of practices and techniques in making and (un)making come to the fore. And, with this, an emphasis on ethics and the value of what is produced for whom, by who and when. The question of proximity, then, becomes one of the relation between 'the creation of values and the production of subjectivity' (Arnott n.d.).

The word 'intimate' has been used to conjure this value of craft in producing connections of a human scale; a hapti(city), close to hand. There is a further connection with an observed, contemporary view of the modern city as an intimate metropolis 'predicated on the concept of the private individual, and on the sanctity of the individuals; inmost thoughts and feelings' (di Palma et al. 2009: 1). The craft and design practices offered here shift from intimate, as ego, to an idea of connections that are close and haptic; where outcomes are not determined in advance but through doing, through doing as learning, crafting as a particular and singular relation with making and matter. 
This issue of craft + design enquiry is a vehicle for thinking through the potential and qualities of this practice within the contemporary situation of urban density and globalism in 'the century of the city'. On behalf of each of the papers, as a world in making, addressing cities, craft, design I invite you in ...

Suzie Attiwill is Associate Professor of Interior Design and Deputy Dean of Learning and Teaching, RMIT School of Architecture and Design, Melbourne, Australia. She has an independent practice that involves the design of exhibitions, curatorial work, writing and working on a range of interdisciplinary projects in Australia and overseas. From 1996 to 1999, she was the artistic director of Craft Victoria. She is Executive Editor of The IDEA Journal (2014-16); a founding member of the Urban Interior research group and a professional member, Design Institute of Australia.

\section{Acknowledgements}

I would like to thank Jenny Deves, Managing Editor of craft + design enquiry, for her commitment to the journal; Craft Australia - the organisation that initiated this journal with the vision to foster and nurture craft and design research; the peer reviewers, whose insights and comments make a critical contribution to the content of the journal; all the authors who submitted proposals and, in particular, those who have stayed involved with this process since 2011; and, to Norman Davis, for his commentary and conceptual reorientations.

\section{References}

Arnott, S., n.d., 'Liminal subjectivity and the ethico-aesthetic paradigm of Félix Guattari', viewed 29 Mar. 2008 http://limen.mi2.hr/limen1-2001/stephen_ arnott.html

Attiwill, S., 2008, Interiorist | publi(city), http://www.youtube.com/ watch?v=h0R3IV_-pDg

,-- 2011 , 'Urban and interior: techniques for an urban interiorist', in R.U. Hinkel (ed.), Urban Interior. Informal Explorations, Interventions and Occupations, Germany: Spurbuchverlag, pp. 11-24.

,-- 2013 , '?interior, practices of interiorization, interior design', $\mathrm{PhD}$ research by project, RMIT University, http://researchbank.rmit.edu.au/view/rmit:160402

Buchanan, I., 2005, 'Space in the age of non-place', in I. Buchanan \& G. Lambert (eds.), Deleuze and Space, Edinburgh: Edinburgh University Press, pp. 16-35.

Buchanan, I. \& Lambert, G., 2005, 'Introduction', in Deleuze and Space, Edinburgh: Edinburgh University Press, pp. 1-15. 
Di Palma, V., Periton, D. \& Lathouri, M., 2009, 'Introduction', in: V. di Palma, D. Periton \& M. Lathouri (eds), Intimate Metropolis. Urban subjects in the modern city. London \& New York: Routledge, pp. 1-8.

Grosz, E., 2001, Architecture from the Outside. Essays on virtual and real space, Writing Architecture Series, Massachusetts: MIT.

,-- 2009, 'The thing', in F. Candlin \& R. Guins (eds.), The Object Reader. London \& New York: Routledge, pp. 124-38.

Guattari, F., 2008, The Three Ecologies, London: Continuum.

Massumi, B., 2002, Parables for the Virtual. Movement, Affect, Sensation. Durham, London: Duke University Press.

Murphie, A., 2008, 'Clone your technics. Research creation, radical empiricism and the constraints of models', INFLEXion: A journal for research creation, vol. 1, no. 1: How is research-creation? pp. 1-34.

Tibaijuka, A.K., 2010, Inaugural Address, UN Pavilion Lecture Series, Shanghai World Expo 2010, viewed 24 April 2011, http://www.unhabitat.org/content. asp?cid $=8273 \&$ catid $=560 \&$ typeid $=8 \&$ subMenuld $=0$ 